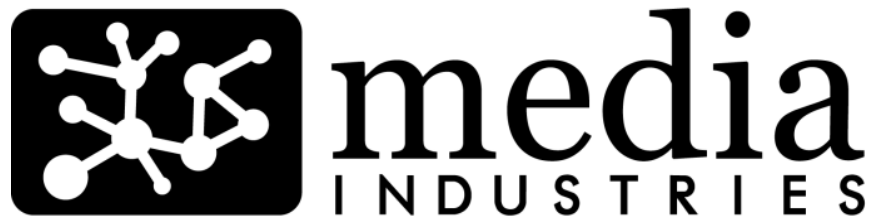

\section{Global, Regional, Transnational, Translocal}

\author{
Joe Straubhaar ${ }^{1}$ \\ University of Texas \\ jdstraubhaar [AT] mail.utexas.edu
}

\begin{abstract}
:
The globalization of media industries has proceeded by a process of accumulation or sedimentation of layers or spaces that burst upon the world media stage but gradually take their place as parts, often very important parts, of complex industries such as television. One of the first ways that this process became visible, historically, was through the growth of different kinds of television to fill different spaces. To continue this theoretical reexamination, several key moments from the example of Brazilian network television are examined and theorized. It is a prominent case of a cultural industries' growth from import substitution to increasing national self-sufficiency and then to transitional and global prominence as an exporter.
\end{abstract}

Keywords: Global Television, Regionalism, Transnationalism, Cultural Imperialism, Brazil

In the excitement and hubris of youth and doctoral study fieldwork in the late 1970s, I argued that cultural dependency and cultural imperialism, at least in the Brazilian television industry, were being transformed, or Brazilianized. Given what I had read in graduate school by Herbert Schiller and others in terms of cultural imperialism and dependency, ${ }^{2}$ I had expected a penetration of Brazil's media by US-style capitalism, by institutions such as advertising agencies, ${ }^{3}$ by multinational advertisers, ${ }^{4}$ by direct investment from US companies, ${ }^{5}$ and by the co-optation of national elites. ${ }^{6}$ Further, Schiller argued that both US industry and government had a desire to control media in other countries in order to create ideological support for a capitalist transformation. Looking at Latin America in the 1970s, Luis Ramiro Beltrán, a contemporary of Schiller and one of the main critics of development in Latin American communications study, thought he saw evidence of such ideological dominance. ${ }^{7}$ Both theory and initial empirical studies predicted an overwhelming one-way flow of film, ${ }^{8}$ news, ${ }^{9}$ and television from the US to other countries. ${ }^{10}$ Some went so far as to predict "Wall-to-Wall Dallas," 11 in part because US culture, genres, and production values were assumed to be overwhelmingly attractive to audiences elsewhere. The outcome most feared by political economy scholars was cultural homogenization,12 or synchronization and loss of autonomy on the part of individual nations. ${ }^{13}$

Yet what I had found already by the late 1970s in Brazil did not fit the holistic pattern of imperialism argued for by Schiller. Instead, I discovered a Brazilian television prime time full 
of local telenovelas, whose ratings showed that they were much more popular than any imported US programs. This observation led me eventually to articulate a counter-theory of the attraction of cultural proximity: that the cultural products most relevant to a local cultureeither its own or from nearby or similar cultures - would be most popular. ${ }^{14}$ Foreign capital, at least in the television industry, had been chased out in the early 1970s, particularly since it violated the Brazilian constitution, which anticipated and prohibited such outside interference. Brazilian entrepreneurs clearly used US network models, but they also adapted them heavily.

The then proponents of cultural dependency and cultural imperialism theories were committing a mistake much like the one being made by some globalization theorists and researchers today. They overgeneralized from rapid changes in economics, economic paradigms, technology, and infrastructure to presume equivalent changes in production, content, and reception. However, my approach risked underestimating the accurate core of what political economists perceived because of the overreach of cultural imperialism theory.

In the 1970s, I did see evidence for a real trend toward the active agency of owners, administrators, producers, writers, and so forth. These Brazilian industry professionals were blending US and Brazilian economic models, administrative models, and programming ideas, thereby creating distinctive genres, like the telenovela, from a variety of sources, including US genres like the soap opera. In the 1980s, when I had a chance to do more reception-oriented research, I found a distinct preference for Brazilian programming, which was linked to a notable national impact of television in creating an imagined national community and identity. ${ }^{15}$ However, I severely underestimated the underlying power of increasingly global capitalism, of the implantation of a mass consumer model, and of the increasing incorporation of Brazil into an integrated global economy. A key question, then, is how to resolve these tensions between what political economy tends to perceive accurately and what cultural studies tends to perceive accurately-hopefully seeing more clearly the impacts of both structure and agency in the process.

\section{Problematizing the Global, Transnational, and National}

The (over)use of the word global often tends to lead people to expect that most of the things we look at, above and below the level of the nation-state itself, are global. While macro politicaleconomic structures and technological infrastructures may have truly global impacts, many other aspects of media industry are more often constrained or structured within domains of language and culture.

The capitalist system has been steadily penetrating more and more of the world, slowly pulling even those countries that resisted it most, such as Albania, China, and the USSR, into its orbit. ${ }^{16}$ Advertisers, ad agencies, international program sellers, US commercial networks, media equipment manufacturers, and so forth have all tended to pull media institutions around the world into a more commercial mode of operation that articulated better with global capitalism.

In Brazil, older institutions - those not so attuned to advertising as the prime base of support, less well structured as commercial networks, and less well positioned to produce commercial programming that pleased both advertisers and audiences-declined in ratings in the 1960s and '70s. The new institutions that arose, like TV Globo, were far more adept at creating a national network, 17 refining genres like telenovelas for commercial production, ${ }^{18}$ selling advertising, ${ }^{19}$ and, in a broad sense, helping to pull the population into a commercial economy and to cast them as consumers. Some of this transformation and adaptation took place earlier 
at the regional level, where both commercial broadcasting and genre ideas from the United States were already being adapted and transformed in Cuba since the 1950s.

The case of telenovelas is a key example, carrying national, regional, and transnational cultural-linguistic, and global resonance, since TV Globo has been one of the few developingcountry networks to export globally since the 1970s. ${ }^{20}$ At one level, the expansion of global capitalism succeeded dramatically in terms of advertising global products and pulling millions of people into an upcoming economy (what are called the BRICs-Brazil, Russia, India, and China) as consumers. Observing this success, one economist pondered whether, if programming in Brazil still helped to sell soap, it mattered that the programming was Brazilian. ${ }^{21}$ This inquiry shows both the strengths and weaknesses of political economy as an approach: it is quite right at the level of economics and the sociology of consumer society but misses the importance of culture itself. A wave of nationally oriented cultural studies in Latin America in the 1980s and 1990s showed that the cultural content of television programming mattered a great deal to individuals' understanding of cultural identity - national identity plus racial, gender, class, subcultural, and religious identities and subjectivities, as well. ${ }^{22}$

Another wave of studies since the 1990s, heralded most prominently by Sinclair, Jacka, and Cunningham, has attended to the regional level of analysis of media industry. ${ }^{23}$ This includes examining national networks as primary actors but also involves fleshing out levels of analysis between the local, national, and global. Similarly, others are looking at cultural-linguistic spaces such as the Anglophone, Francophone, or Lusophone, which have built on older empires that reached beyond geographic regions like Latin America. ${ }^{24}$

To conclude, let us return to Brazil as an example. To understand the media industry there, one must examine it on multiple levels: the country's internal media regionalism, ${ }^{25}$ the strong national media such as TV Globo, and its global media cities, Rio de Janeiro and São Paulo. ${ }^{26}$ Transnationally, one must look at Brazil's role as exporter of programs, genres, formats, and models in the region of Latin America and its similar, even more dominant role in the Lusophone cultural-linguistic space that includes Angola, Mozambique, and Portugal. ${ }^{27}$ An understanding of Brazil's political economic place in the global capitalist system - where it has been elevated into the ranks of up-and-coming global BRICs-is essential. ${ }^{28}$ But so is an understanding of the cultural complexity of its racial, religious, and other mixtures in the context of the African diaspora, ${ }^{29}$ as well as its diverse internal cultural geography of cities, distinctive state, and regions..$^{30}$

1 Joe Straubhaar is Amon G. Carter Sr. Centennial Professor of Communications in the Radio-Television-Film Department of the University of Texas. He is also Director of the Latino and Latin American Media Studies Program in the College of Communications. He is coauthor with John Sinclair of Latin American Television Industries (BFI/Palgrave, 2013).

2 Herbert I. Schiller, Mass Communication and American Empire (Boston: Beacon, 1969).

3 Fred Fejes, "The Growth of Multinational Advertising Agencies in Latin America," Journal of Communication 30, no. 4 (1980): 36-49.

4 Elizabeth de Cardona, "Multinational Television," Journal of Communication 25, no. 2 (1975): 122-27; Luis Ramiro Beltran and Elizabeth Fox de Cordona, Comunicacion 
Dominada: Estados Unidos en Los Medios de America Latina (Mexico City: Instituto Latinoamericano de Estudios Transnacionales, Editorial Nueva Imagen, 1980).

5 Luis Ramiro Beltran and Elizabeth Fox de Cordona, Comunicacion Dominada

6 Theotonio dos Santos, "The Crisis of Development Theory and Problems of Departure in Latin America," in Underdevelopment and Development: The Third World Today, ed. Henry Bernstein (Baltimore: Penguin, 1973): 64-76.

7 Luis Ramiro Beltran, "TV Etchings in the Minds of Latin Americans: Conservatism, Materialism, and Conformism," Gazette 24, no. 1 (1978): 61-65.

8 Schiller, Mass Communication and American Empire; Kaarle Nordenstreng and Tapio Varis, Television Traffic: A One-Way Street (Paris: UNESCO, 1974); Thomas Guback, "International Circulation of US Theatrical Films and Television Programming," in World Communications, ed. George Gerber and Marsha Siefert (New York: Longman Incorporated, 1984), 153-63.

9 Oliver Boyd-Barrett, The International News Agencies (Beverly Hills: Sage, 1980).

10 Nordenstreng and Varis, Television Traffic.

${ }^{11}$ Richard Collins, "Wall-to-Wall Dallas? The US-UK Trade in Television," Screen (MayAugust): 66-77.

12 Chin-Chaun Lee, Media Imperialism Reconsidered (Beverly Hills: Sage, 1980).

${ }^{13}$ Cees J. Hamelink, "Cultural Autonomy Threatened," in Cultural Autonomy in Global Communications, ed. Cees J. Hamelink (London: Langman Group, 1983), 1-25.

14 Joseph Straubhaar, "Beyond Media Imperialism: Asymmetrical Interdependence and Cultural Proximity," Critical Studies in Mass Communication 8 (1991): 39-59.

15 Benedict Anderson, Imagined Communities: Reflections on the Origin and Spread of Nationalism (New York: Verso, 1983); Mauro Pereira Porto, "Telenovelas and Representations of National Identity in Brazil," Media, Culture E Society 33, no. 1 (2011): 53-69.

16 Immanuel Wallerstein, The Capitalist World Economy (Cambridge: Cambridge University Press, 1979).

17 J. Wallach, Meu Capítulo na TV Globo (Rio de Janiero: Editora Topbooks, 2011).

18 Jose Bonifácio de Oliveira Sobrinho, O Livro Do Boni (Rio: A Casa de Palavra, 2011).

19 Wallach, Meu Capítulo na TV Globo.

20 Jose Marques de Melo, As Telenovelas de Globo (Sao Paulo: Summus, 1988).

${ }^{21}$ Omar Souki Oliveira, "Brazilian Soaps Outshine Hollywood: Is Cultural Imperialism Fading Out?," in Beyond National Sovereignty: International Communication in the 1990s, ed. Kaarle Nordenstreng and Herbert Schiller (Norwood: Ablex, 1993), pp. 116-31.

22 O. F. Leal, A Leitura Social da Novela das Oito (Petropolis, Brazil: Vozes, 1986).

${ }^{23}$ John Sinclair, Elizabeth Jacka, and Stuart Cunningham, eds., New Patterns in Global Television (New York: Oxford University Press, 1996).

24 Joseph D. Straubhaar, World Television: From Global to Local. Thousand Oaks, CA: Sage, 2007).

25 Cicilia M. Krohling Peruzzo, "Mídia Regional e Local: Aspectos Conceituais e Tendências," Comunicação \& Sociedade 1, no. 38 (2005): 67-84.

${ }^{26}$ Michael Curtin, "Media Capital: Towards the Study of Spatial Flows," International Journal of Cultural Studies 6, no. 6 (2003): 202-28.

27 John Sinclair and Joseph Straubhaar, Latin American Television Industries (London: British Film Institute, 2013). 
28 Jim O’Neill, "Building Better Global Economic BRICs," Goldman-Sachs, GS Global Economics, last modified 2001.

${ }^{29}$ Michael L. Conniff, and T. J. Davis, Africans in the Americas: A History of the Black Diaspora (New York: St. Martin's, 1994).

30 Arturo Escobar, "Culture Sits in Places: Reflections on Globalism and Subaltern Strategies of localization," Political Geography 20, no. 2 (2001): 139-74; Charles A. Perrone and Christopher Dunn, eds., Brazilian Popular Music $\mathcal{E}$ Globalization (London: Routledge, 2012).

\section{Bibliography}

Anderson, Benedict. Imagined Communities: Reflections on the Origin and Spread of Nationalism. New York: Verso, 1983.

Beltran, Luis Ramiro. "TV Etchings in the Minds of Latin Americans: Conservatism, Materialism and Conformism." Gazette 24, no. 1 (1978): 61-65.

Beltran, Luis Ramiro, and Elizabeth Fox de Cardona. Comunicacion dominada: Estados Unidos en los medios de America Latina. Mexico City: Instituto Latinoamericano de Estudios Transnacionales, Editorial Nueva Imagen, 1980.

Bonifácio de Oliveira Sobrinho, Jose. O Livro Do Boni. Rio: A Casa de Palavra, 2011.

Boyd-Barrett, Oliver. The International News Agencies. Beverly Hills: Sage, 1980.

Cardona. Elizabeth de. "Multinational Television." Journal of Communication 25, no. 2 (1975): 122-27.

Collins, Richard. “Wall-to-Wall Dallas? The US-UK Trade in Television." Screen (May-August): 66-77.

Conniff, Michael L., and T. J. Davis. Africans in the Americas: A History of the Black Diaspora. New York: St. Martin's, 1994.

Cunningham, Stuart, Elizabeth Jacka, and John Sinclair, eds. New Patterns in Global Television. New York: Oxford University Press, 1996.

Curtin, Michael. "Media Capital: Towards the Study of Spatial Flows." International Journal of Cultural Studies 6, no. 6 (2003): 202-28.

Dos Santos, Theotonio. "The Crisis of Development Theory and Problems of Departure in Latin America." In Underdevelopment and Development: The Third World Today, edited by Henry Bernstein. Baltimore: Penguin, 1973: 64-76

Escobar, Arturo. "Culture Sits in Places: Reflections on Globalism and Subaltern Strategies of Localization." Political Geography 20, no. 2 (2001): 139-74.

Fejes, Fred. "The Growth of Multinational Advertising Agencies in Latin America." Journal of Communication 30, no. 4 (1980): 36-49.

Guback, Thomas. "International Circulation of US Theatrical Films and Television Programming." In World Communications, edited by G. Gerber and M. Siefert, 153-63. New York: Longman, 1984. 
Hamelink, Cees J. “Cultual Autonomy Threatened.” In Cultural Autonomy in Global Communications, edited by Cees J. Hamelink, 1-25. New York: Longman, 1983.

Lee, Chin-Chuan. Media Imperialism Reconsidered. Beverly Hills: Sage, 1980.

Marques de Melo, José. As Telenovelas da Globo. Sao Paulo: Summus, 1988.

Nordenstreng, Kaarle, and Tapio Varis. Television Traffic: A One-Way Street. Paris: UNESCO, 1974.

O’Neill, Jim. “Building Better Global Economic BRICs.” Goldman-Sachs. GS Global Economics. Last modified 2001.

Oliveira, Omar Souki. “Brazilian Soaps Outshine Hollywood: Is Cultural Imperialism Fading Out?" In Beyond National Sovereignty: International Communication in the 1990s, edited by Kaarle Nordenstreng and Herbert Schiller, 116-47. Norwood: Ablex, 1993.

Peruzzo, Cicilia M. Krohling. "Mídia Regional e Local: Aspectos Conceituais e Tendências." Comunicação \& Sociedade 1, no. 38 (2005): 67-84.

Porto, Mauro Pereira. “Telenovelas and Representations of National Identity in Brazil." Media, Culture E Society 33, no. 1 (2011): 53-69.

Schiller, Herbert I. Mass Communication and American Empire. Boston: Beacon, 1969.

Sinclair, John, and Joseph Straubhaar. Television Industries in Latin America. London: British Film Institute, Palgrave Macmillan, 2013.

Straubhaar, Joseph. “Beyond Media Imperialism: Asymmetrical Interdependence and Cultural Proximity," Critical Studies in Mass Communication 8 (1991): 39-59

Straubhaar, Joseph. World Television: From Global to Local. Beverly Hills: Sage, 2007.

Straubhaar, Joseph. "Telenovelas in Brazil: From Traveling Scripts to a Genre and Proto-Format Both National and Transnational." In Global Television Formats: Understanding Television across Borders, edited by Tasha Oren and Sharon Shahaf, 148-77. New York: Routledge, 2011.

Wallach, Joe. Meu Capítulo na TV Globo. Rio de Janiero: Editora Topbooks, 2011.

Wallerstein, Immanuel. The Capitalist World Economy. Cambridge: Cambridge University Press, 1979.

\section{(cc) $\mathrm{BY}-\mathrm{NC}-\mathrm{ND}$}

Copyright (C) 2015 (Joe Straubhaar). Media Industries is an open-access, peer-reviewed, online academic journal. As such, we aim to participate in the open exchange of information. This work is licensed under a Creative Commons Attribution Noncommercial No Derivatives (by-nc-nd) License. Under this license, this work is available for sharing and noncommercial distribution provided the appropriate attribution is given. 